\title{
Perancangan Sistem Informasi Pengguna Izin Frekuensi Kantor Balai Loka Monitor Spektrum Frekuensi Radio Ternate Berbasis Web
}

\author{
Bernad Ludu ${ }^{1}$, Irwan Lasaleh ${ }^{2}$ \\ Program Studi Teknik Komputer \\ Akademi Ilmu Komputer Ternate \\ bernad_ludu@yahoo.com
}

\begin{abstract}
Abstrak
Kantor Balai Loka Monitor Spekrum Frekuensi Radio (Kemkominfo) merupakan salah instansi pada kemkominfo yang mengelola izin frekuensi yang ada di ternate provinsi maluku utara, dalam mengelola data izin dan pembuatan Izin Pengguna Frekuensi Stasiun Radio (ISR) masih dilakukan secara manual mengunakan sistem komputerisasi aplikasi microsoft word dan excel, yang dalam pelaksanaannya terasa kurang efektif dan efesien. Penelitian ini dilakukan di Kantor Balai Loka Monitor Spekrum Frekuensi Radio (Kemkominfo) Maluku Utara bertujuan untuk Merancang Sistem Informasi Pembuatan Izin pengguna Frekuensi Radio Berbasis Web pada Kantor Balai Loka Monitor SFR, (Kemkominfo), dengan menggunakan PHP serta MySQL sebagai data basenya. Metode Pengumpulan Data menggunakan observasi, wawancara. Sistem ini dirancang menggunakan model diagram alir data (DAD) dengan bahasa pemrograman PHP serta MySQ1 sebgai Databasenya. Dengan adanya sistem ini diharapkan dapat mempermudah petugas, dan pemohon, untuk mengakses Program dalam mengetahui tentang permohonan Izin Stasiun Radio (ISR) serta tempat pembuatan ISR disistem
\end{abstract}

\section{Kata kunci: Sistem Informasi, Izin Frekuensi Radio, Website}

\section{Abstract}

Office Loka Spekrum Radio frequency Monitor (Kemkominfo) is a government agency that manages the kemkominfo permission on the frequencies that are in ternate the North maluku province, in the manage data permissions and User Permissions making Radio station Frequency (ISR) are still done manually using computerized system applications Office word and excel which in i'ts execution feels less effectively and efficiently. This research was conducted in the Office Hall Loka Spekrum Radio frequency Monitor (Kemkominfo), using PHP and MySQL as a data basenya. Data collection method using observation, interviews, The system is designed using model data flow diagram (DAD) and the PHP programming language and MySQl as the database, The existence of this system are expected to facilitate the applicant's officers to access the Program in knowing about applying for the permission of the Radio station (ISR) as well as the manufacture of ISR in this sistem

\section{Keywords: Information Systems, Radio Frequency Permits, Website}

\section{PENDAHULUAN}

Salah satu pengembangan sistem informasi dalam dunia teknologi informasi saat ini adalah dapat membantu manusia dalam menyelesaikan pekerjaan-pekerjaan secara cepat khususnya dalam proses pengolahan data. Semua informasi yang berkaitan erat dengan pengolahan data harus bisa disajikan tepat pada waktunya. Namun pada Kantor Balai Loka Monitor Spektrum Frekuensi Radio (Kemkominfo) Ternate yang bertugas dalam mengeluarkan dan pembuatan Izin Pengguna Frekuensi sudah mengunakan sistem komputerisasi, tetapi masih dilakukan secara manual dengan 
mengunakan aplikasi word, exel, dan dalam pelaksanaan kurang efektif dan efesien. Namun dalam penyusunan Tugas Akhir ini untuk merancang suatu Sistem Informasi pembuat Izin Stasiun Radio (ISR) menggunakan Komputerisasi.

Penggunaan spektrum frekuensi radio harus mendapatkan izin dari Direktorat Jendral Sumber Daya dan Perangkat Pos dan Informatika (SDPPI). Kementrian Komunikasi dan Informatika RI. Beberapa contoh Pengguna Spektrum frekuensi radio yang harus dengan Izin Stasiun Radio (ISR) yaitu:

Radio Siaran (FM dan AM), TV Siaran, Penyelenggaraan Komunikasi Radio, SSB, HT, Base Station, Mobile Unit, Radio Taxi, Dan lain - lain. Izin Stasiun Radio (ISR) harus diajukan langsung melalui loket resmi Direktorat Operasi Sumber Daya Ditjen SDPPI Kementrian Kominfo atau melalui Loket pelayanan Loka Monitor Spektrum Frekuensi Radio Ternate, tidak melalui pihak ketiga (Calo).

Mengetahui kepadatan pengguna Spektrum Frekuensi Radio dalam upaya pencegahan terjadi Interfrensi, mengetahui kepastian legalitas pengguna Frekuensi Radio sesuai dengan ketentuan yang berlaku. Tercipta ketaatan dalam pemanfaatan dan pengguna Spektrum Frekuensi Radio secra efektif dan efesien serta sesuai dengan peruntukan.

Dan oleh karena itu berdasarkan gambaran hal tersebut di atas maka di anggap perlu untuk mendesain suatu sistem informasi pengolahan data pembuatan Izin pengguna frekuensi radio pada Kantor Balai Loka Monitor SFR (Kemkominfo) Ternate dengan menggunakan PHP dan My Sql sebagai data basenya merupakan perangkat lunak yang menawarkan begitu banyak kemudahan dan keunggulan dalam proses pembuatan aplikasi data base

\section{Rumusan Masalah}

Berdasarkan latar belakang diatas, pokok permasalahan terdapat pada pengaksesan data pengguna izin frekuensi dengan menggunakan Aplikasi Word, Exsel dan bahasa pemograman sederhana berupa Visual Foxpro sehingga menampilkan hasil yang kurang memuaskan, maka penulis mengemukakan pokok permasalahannya adalah bagaimana merancang Sistem Informasi Pembuatan Izin pengguna Frekuensi Radio Berbasis Web pada Kantor Balai Loka Monitor SFR, (Kemkominfo) Ternate dengan menggunakan PHP serta MySQL sebagai data basenya.

\section{Tujuan Penelitian}

Merancang Sistem Informasi Pembuatan Izin pengguna Frekuensi Radio Berbasis Web pada Kantor Balai Loka Monitor SFR, (Kemkominfo) Ternate dengan menggunakan PHP serta MySQL sebagai data basenya.

\section{Manfaat Penelitian}

Manfaat Penelitian yang diharapkan adalah untuk lebih mempermudah petugas dalam mengakses Izin pengguna Frekuensi Radio Berbasis Web pada Kantor Balai Loka Monitor SFR, (Kemkominfo) Ternate.

\section{Tinjauan Pustaka}

Berdasarkan tinjauan pustaka yang di lakukan oleh penulis, penelitian tentang pembuatan pengguna izin frekuensi yang dilakukan oleh beberapa pihak yaitu:

Perancangan sistem Informasi Pengolahan Data Peminjaman buku daera 
perpustakaan Kota Ternate dengan menggunakan bahasa Pemograman Visual Delphi dan basis datanya Microsoft Acces 2003 (Irsan Dengo, 2012),

Pengaruhnya pengawasan terhadap Lalulintas Hewan, maka dirancang Sistem Informasi data hewan pada Kantor Balai Karantina Pertanian Kelas II Ternate, dengan Menggunakan Pemograman Visual Basic dan basis datanya Microsoft Acces 2003 (M. Idham Abbas dan Zulfazri Muhammad, 2013).

Berdasarkan Tinjauan pustaka di atas, maka berbeda dengan judul yang di usulkan oleh penulis yaitu dalam pengguna program Aplikasi serta tempat penelitian. Dimana bahasa pemograman yang digunakan untuk membuat Sistim Informasi pengguna Izin Stasiun Radio (ISR) pada Kantor Balai Loka Monitor Spektrum Frekuensi Radio (Kemkominfo) Ternate dengan menggunakan bahasa Program PHP dan My Sql sebagai Data Basenya, sedangkan Penelitian sebelumnya menggunakan Visual Delpi serta Visual foxpro dan Basis Datanya Microsoft Acces 2003

\section{LANDASAN TEORI}

\section{Pengertian Sistem Informasi}

Sistem informasi adalah data yang dikumpulkan, dikelompokkan dan diolah sedemikian rupa sehingga menjadi sebuah satu kesatuan informasi yang saling terkait mendukung sehingga menjadi suatu informasi yang berharga bagi yang menerimaannya.

\section{Pengertian Perancangan Sistem}

Perancangan sistem merupakan merancang output, input struktur file, program, prosedur, perangkat keras dan perangkat lunak yang diperlukan untuk mendukung sistem informasi, atau perancangan sistem merupakan pengembangan sistem baru dari sistem lama yang ada, dimana masalah-masalah yang terjadi pada sistem lama di harapkan sudah teratasi pada sistem yang baru

\section{Data Flow Diagram (DFD)}

Data flow diagram adalah suatu diagram yang menggunakan notasi-notasi untuk menggambarkan aliran data dalam sebuah sistem. DFD menggambarkan semua proses, merupakan proses tersebut terjadi dalam waktu yang berbeda

\section{Kamus Data}

Kamus data atau data directory (DAD) adalah katalok fakta tentang data dan kebutuhan-kebutuhan informasi dari suatu sistem. Informasi kamus data digunakan untuk mendefenisikan data yang mengalir pada sistem secara lengkap

\section{Rancangan Output}

Jenis output sistem dapat berupa tampilan di layar monitor (softcopy) atau cetakan pada media keras (hardcopy), sperti kertas atau microfilm. Perancangan output sistem adalah berupa penentuan kebutuhan output sistem yang baru dan penentuan parameter output. Kebutuhan output sistem baru dapat diketahui dari DAD, yaitu arus data dari suatu proses ke satuan luar atau dari suatu proses ke proses lain. Output sistem berupa laporanlaporan, dapat digunakan untuk menentukan bentuk/format dan tata letak laporan tersebut. Perancangan output bertujuan menentukan keluaran-keluaran yang akan digunakan oleh sistem, keluaran tersebut berupa tampilan-tampilan layar, format, dan juga frekuensi laporan yang ditunjukkan. 


\section{Rancangan Input}

Rancangan input adalah pada tahap penganalisis pengumpulan informasiinformasi yang terkumpul sebelumnya untuk mencapai desain sebuah sistem infrormasi. Penganalisis juga merancang prosedur data sedemikian rupa sehingga data yang dimasukkan kedalam sistem informasi benar-benar akurat, itu juga penganalisis menggunakan teknik/bentuk tertentu untuk menjamin kualitas input sistem informasi

\section{Rancangan Basis Data}

Basis data (Database) merupakan kumpulan data yang saling berhubungan atau berelasisatu dengan yang lainnya. Tersimpan di perangkat keras komputer dan digunakan perangkat lunak untuk memanipulasinya, Database merupakan salah satu komponen yang penting di sistem informasi. Bagi para pemakainya penerapan database dalam sistem informasi tersebut dengan database sistem, basis data (database sistem) ini adalah suatu informasi yang mengintegrasikan kumpulan dari data yang saling berhubungan satu dengan yang lain dan membuatnya tersedia untuk beberapa aplikasi yang bermacam-macam di dalam suatu organisasi

\section{ERD (Entity Relation Diagram)}

$\begin{aligned} & \text { Entity } \\ & \text { Relationship Diagram } \\ & \text { adalah }\end{aligned}$ (ERD)
mendeskripsikan $\begin{array}{r}\text { konsep } \\ \text { hubungan }\end{array}$
penyimpanan dan didasarkan
persepsi dari sebuah dunia nyata yang
terdiri dari sekumpulan objek, disebut
entiti \& relasi diantar objek-objek tersebut.
Atau juga bisa disebut suatu model
jaringan (network) yang menggunakan
susunan data yang disimpan dari sistem
secara abstrak.

Fungsi dari penggambaran ERD adalah:

a. Untuk memodelkan struktur data dan hubungan antar data.

b. Model dapat diuji dengan mengabaikan proses yang dilakukan.

c. Menjelaskan hubungan antar data dalam basis data ber dasarkan objek - objek dasar data yang mempunyai hubungan antar relasi yang 1 ke relasi yang lain yang di sebut ERD.

Mendokumentasikan data - data yang ada dengan cara mengidentifikasi tiap jenis entitas dan hubungannya

\section{Rancangan Teknologi}

Teknologi yang digunakan didalam sistem teknologi informasi ini adalah teknologi komputer, teknologi telekomonikasi dan berbagai teknologi apapun yang dapat memberikan nilai tambah untuk suatu organisasi.

Sistem teknologi informasi dapat diterapkan di bagian internal dan eksternal organisasi.di internal organisasi sistem informasi dapat di terapkan di fungsifungsi organisasi dan pada tingkat manajemen.sistem teknologi informasi yang diterapkan secara eksternal merupakan sistem teknologi informasi internal yang di tarik keluar organisasi menggunakan teknologi komunikasi

\section{Implementasi Sistem}

Implementasi sistem (sistem implementation) adalah prosedur yang dilakukan untuk menyelesaikan desain dalam dokumen desain sistem yang disetujui dan menguji, menginstal, memulai, serta menggunakan sistem yang baru atau sistem yang diperbaiki.penggunakan suatu komputer untuk pemecahan masalah membutuhkan suatu sistem yang baik, sehingga memungkinkan berhasilnya komputer 
dalam melaksanakan tugasnya, yaitu mengolah data menjadi informasi

\section{Pengertian Data Pembuatan Izin Pengguna Frekuensi Radio}

Pengguna Spektrum frekuensi radio harus mendapatkan izin dari Direktorat Jendral Sumber Daya dan Parangkat Pos dan Informatika RI. Beberapa contoh pengguna spektrum frekuensi radio yang harus dilengkapi dengan Izin Stasiun Radio (ISR) yaitu: Radio siaran (FM dan AM), TV siaran, Penyelenggaraan Komunikasi Radio:SSb, RIG, HT, Base Station, Mobile Unit, Repeater, dan Radio taxi,dll

\section{Bahasa Pemrogram PHP}

PHP adalah singkatan dari Hypertext Processor, yang merupakan sebuah bahasa scripting yang terpasang pada HTML. Tujuan utama PHP adalah untuk membuat sebuah web yang dinamis. Web dinamis merupakan web yang didalamnya terdapat masukan, proses, dan keluaran. Halaman web biasanya disusun dari kode-kode html yang disimpan dalam sebuah file berekstensi. File html ini dikirimkan oleh server atau file ke browser, kemudian browser menterjemahkan kode-kode tersebut. PHP menyatu dengan tag HTML, dieksekusi di server dan digunakan untuk membuat halaman web yang dinamis seperti ASP (Active Server Pages) dan JSP (Java Server Pages). PHP dapat berjalan di berbagai sistem operasi seperti windows 98/NT, UNIX/LINUX, solaris maupun macintosh

\section{MySQL}

MySQL (My Structure Query Language) termasuk database relasional (RDBMS), dan berbasis SQL dengan menggunakan konsep client-server, kelebihan dari MySQL adalah cepat, kuat, serta mudah digunakan, sehingga kita dapat dengan mudah menyimpan, mengubah, dan mengakses data dan informasi. MySQL (My Structure Query Language) adalah sebuah program pembuat database yang bersifat open source, artinya siapa saja boleh menggunakannya dan tidak dicekal atau dengan kata lain gratis, MySQL merupakan database yang bersifat online sehingga dapatdigunakan untuk aplikasi Multi User.

\section{Adobe Dreamweaver}

Adobe dreamweaver atau yang lebih dikenal dengan macromedia dreamweaver adalah sebuah aplikasi yang dikembangkan oleh Adobe System. Macromedia Dreamweaver adalah sebuah HTML editor profesional untuk mendesain secara visual dan mengelola situs web maupun halaman web. Bilamana kita menyukai untuk berurusan dengan kode-kode HTML secara manual atau lebih menyukai bekerja dengan lingkungan secara visual dalam melakukan editing, Dreamweaver membuatnya menjadi lebih mudah dengan menyediakan tool-tool yang sangat berguna dalam peningkatan kemampuan dan pengalaman kita dalam mendesain web. Dreamweaver MX dalam hal ini digunakan untuk web desain.

\section{METODE PENELITIAN}

Metode pengumpulan data yang dilakukan dalam penelitian ini adalah:

\section{Penelitian Pustaka (Library Research)}

Penelitian ini merupakan kajian teoritis yang berhubungan dengan penyusunan tugas akhir, dalam hal penulis menggunakan beberapa buku sebagai referensi.

\section{Penelitian Lapangan (Field Research)}


Penelitian lapangan adalah jenis pengumpulan data dengan melakukan pengamatan langsung dilapangan, dengan menggunakan teknik sebagai berikut:

a. Teknik Observasi adalah teknik yang dilakukan dengan cara mengadakan pengamatan secara langsung mengenai sistem di lapangan. Observasi ini dapat dilanjutkan dengan evaluasi dalam arti secara menyeluruh yang menyangkut dengan input, proses dan hasil.

b. Teknik wawancara (interview) adalah dengan melakukan wawancara dengan pimpinan atau staf untuk mendapatkan data berhubungan dengan Penelitian.

\section{Kerangka Berpikir}

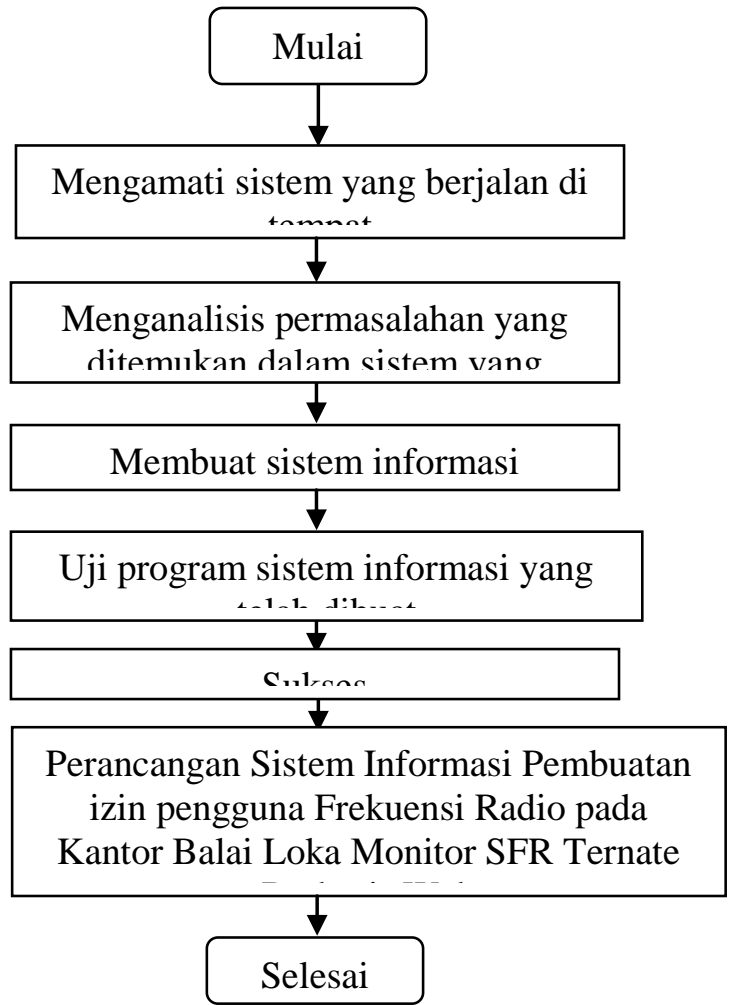

Gambar 1. Kerangka Berpikir
Sesuai dengan analisis sistem yang berjalan pada sistem informasi pengolahan data pembuatan izin pengguna frekuensi radio pada Kantor Balai Loka Monitor SFR (Kemkominfo) Ternate, mengenai pengguna izin frekuensi radio di wilayah Maluku Utara, maka penulis memberikan pemecahan masalah dangan perancangan sistem pengolahan data izin frekuensi. Sistem ini untuk mempermuda petugas untuk mencari informasi yang berhubungan dengan pengguna izin stasiun radio (ISR) kemudian data tersebut di simpan dalam bentuk file yang di proses secara cepat, tepat, dan akurat, untuk mempermudah dalam menghasilkan informasi dimana data tersebut di buat dalam bahasa pemograman PHP dan Mysql Sebagai data basenya, yang kemudian di proses untuk mempermuda petugas dalam menghasilkan infomasi tentang pembuatan izin stasiun radio (ISR) akan di tindak lanjuti
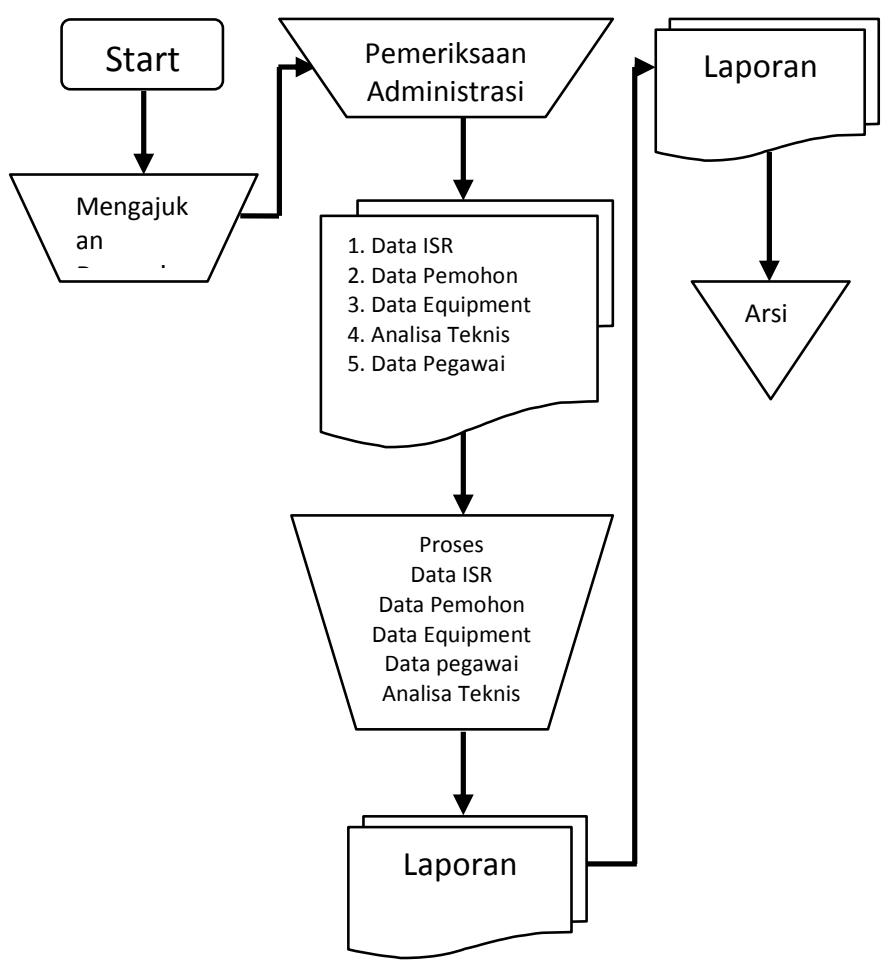

Gambar 2. Analisis Sistem berjalan

ANALISIS DAN PERANCANGAN

Analisis Sistem Yang Berjalan

Analisis Sistem Yang Diusulkan 
Berdasarkan hasil analisa sistem yang berjalan maka diusulkan sistem yang baru yang dapat menunjang sistem yang lama agar dapat efektif dan efisien, berikut merupakan gambar umum rancangan sistem yang diusulkan sebagai berikut:

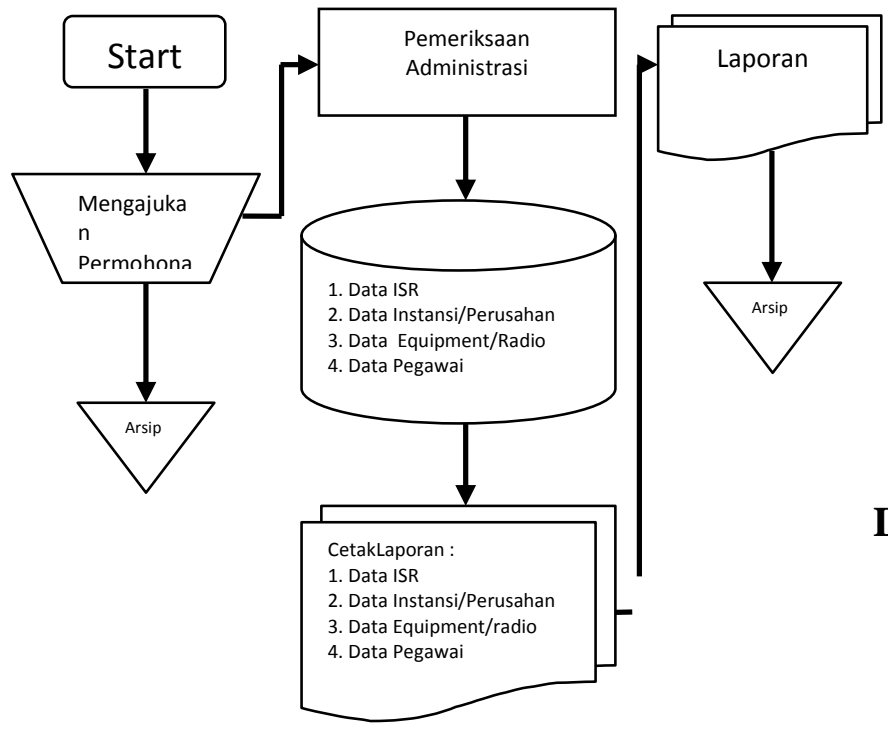

Gambar 3. Analisis Sistem yang diusulkan

\section{Diagram Konteks}

Diagram konteks merupakan pendekatan model desain sistem secara umum yang merupakan kerkangka umum diagram sistem yang diusulkan, berikut merupakan desain gambar diagram konteks

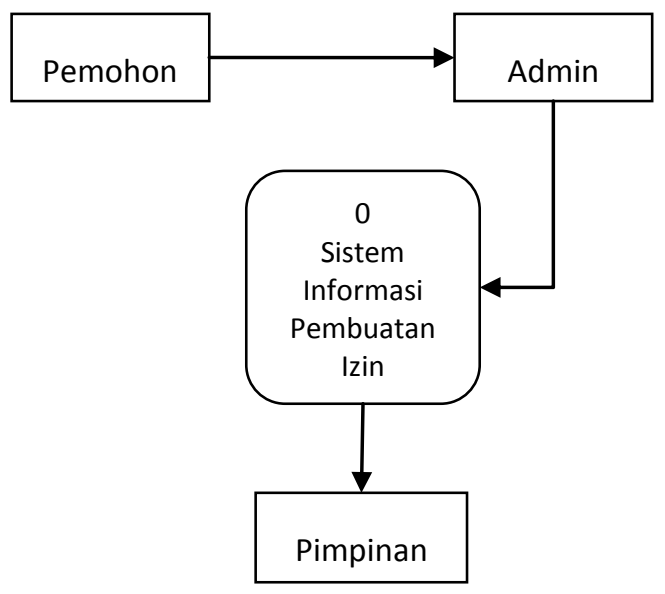

Gambar 4. Diagram Konteks

DAD Level 0

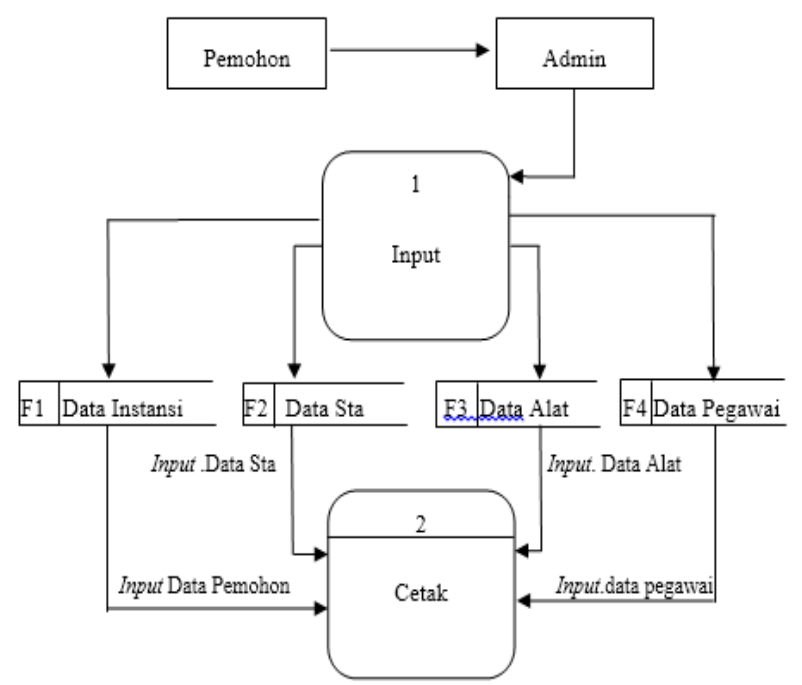

Gambar 5. DFD Level 0

\section{DAD Level 1}

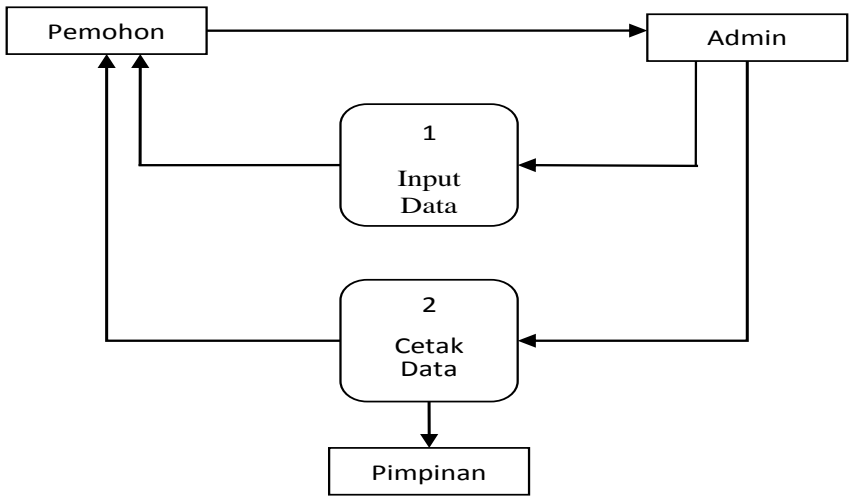

Gambar 6. DFD Level 1

\section{Entity Relationship Diagram (ERD)}

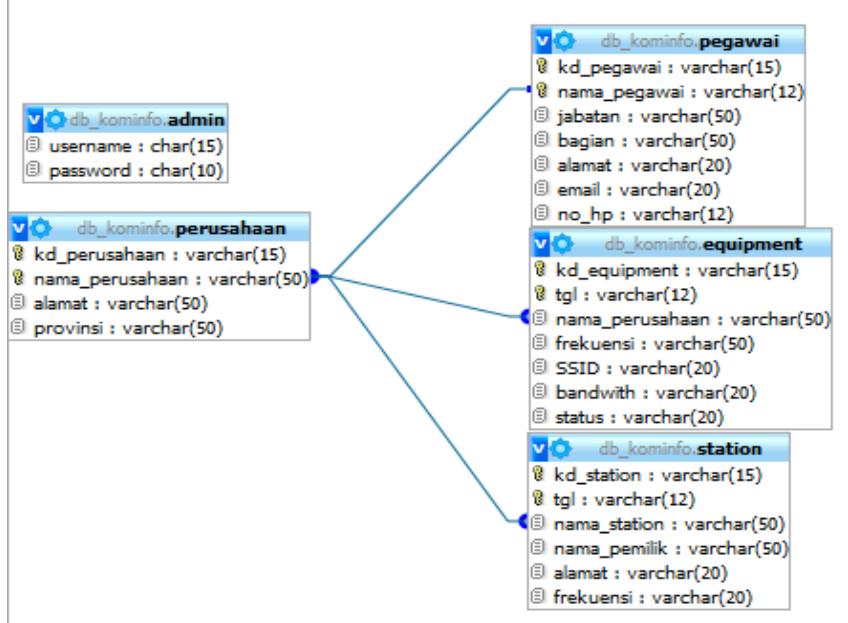

Gambar 8. ERD 


\section{Rancangan Basis Data}

Tabel. 1. Struktur Tabel Data Stasiun.

\begin{tabular}{|c|c|c|c|c|}
\hline $\begin{array}{l}\text { Nama_Fie } \\
\text { Id }\end{array}$ & Type & $\begin{array}{l}\text { Widt } \\
\mathrm{h}\end{array}$ & Index & Keterangan \\
\hline $\begin{array}{l}\text { Kd_stasio } \\
n\end{array}$ & $\begin{array}{l}\text { varch } \\
\text { ar }\end{array}$ & 15 & $\begin{array}{l}\text { Prima } \\
\text { ry key }\end{array}$ & Kode_Stasiun \\
\hline $\begin{array}{l}\text { Nm_stasi } \\
\text { on }\end{array}$ & $\begin{array}{l}\text { varch } \\
\text { ar }\end{array}$ & 50 & & Nama_stasiun \\
\hline $\begin{array}{l}\text { Nm_Pemi } \\
\text { lik }\end{array}$ & $\begin{array}{l}\text { varch } \\
\text { ar }\end{array}$ & 50 & & $\begin{array}{l}\text { Nm_Pemilik_ } \\
\text { stasiun }\end{array}$ \\
\hline Alamat & $\begin{array}{l}\text { varch } \\
\text { ar }\end{array}$ & 20 & & Alamat_stasiun \\
\hline Frekuensi & $\begin{array}{l}\text { varch } \\
\text { ar }\end{array}$ & 20 & & Frekuensi_stasiun \\
\hline $\operatorname{tgl}$ & $\begin{array}{l}\text { varch } \\
\text { ar }\end{array}$ & & & $\begin{array}{l}\text { Tanggal_pendafta } \\
\text { ran }\end{array}$ \\
\hline
\end{tabular}

Tabel. 2. Struktur Tabel Data instansi

\begin{tabular}{|l|l|l|l|l|}
\hline $\begin{array}{l}\text { Nama_Fiel } \\
\text { d }\end{array}$ & Type & $\begin{array}{l}\text { Wid } \\
\text { th }\end{array}$ & Index & Keterangan \\
\hline $\begin{array}{l}\text { Kd_perusa } \\
\text { haan }\end{array}$ & $\begin{array}{l}\text { varc } \\
\text { har }\end{array}$ & 12 & $\begin{array}{l}\text { Prim } \\
\text { ary } \\
\text { key }\end{array}$ & $\begin{array}{l}\text { Koe_Perusahaan/ } \\
\text { instansi }\end{array}$ \\
\hline $\begin{array}{l}\text { Nm_perusa } \\
\text { haan }\end{array}$ & $\begin{array}{l}\text { varc } \\
\text { har }\end{array}$ & 50 & & Nama_Perusahaan \\
\hline alamat & $\begin{array}{l}\text { varc } \\
\text { har }\end{array}$ & 50 & & $\begin{array}{l}\text { Alamat_Perusahaa } \\
\text { n }\end{array}$ \\
\hline Provinsi & $\begin{array}{l}\text { varc } \\
\text { har }\end{array}$ & 50 & & Provinsi \\
\hline
\end{tabular}

Tabel. 3. Struktur Tabel Data pegawai

\begin{tabular}{|l|l|l|l|l|}
\hline Nama_Field & Type & $\begin{array}{l}\text { Widt } \\
\text { h }\end{array}$ & Index & Keterangan \\
\hline kd_Pegawai & $\begin{array}{l}\text { varch } \\
\text { ar }\end{array}$ & 12 & $\begin{array}{l}\text { Prima } \\
\text { ry key }\end{array}$ & $\begin{array}{l}\text { Kode_Pegawa } \\
\text { i }\end{array}$ \\
\hline $\begin{array}{l}\text { Nama_pega } \\
\text { wai }\end{array}$ & $\begin{array}{l}\text { varch } \\
\text { ar }\end{array}$ & 15 & $\begin{array}{l}\text { Nama_pegaw } \\
\text { ai }\end{array}$ \\
\hline jabatan & $\begin{array}{l}\text { varch } \\
\text { ar }\end{array}$ & 50 & & $\begin{array}{l}\text { Jabatan_pega } \\
\text { wai }\end{array}$ \\
\hline bagian & $\begin{array}{l}\text { varch } \\
\text { ar }\end{array}$ & 50 & & $\begin{array}{l}\text { Bagian_pega } \\
\text { wai }\end{array}$ \\
\hline Alamat & $\begin{array}{l}\text { varch } \\
\text { ar }\end{array}$ & 20 & & $\begin{array}{l}\text { Alamat_pega } \\
\text { wai }\end{array}$ \\
\hline email & $\begin{array}{l}\text { varch } \\
\text { ar }\end{array}$ & 20 & & $\begin{array}{l}\text { Email_pegaw } \\
\text { ai }\end{array}$ \\
\hline No_hp & $\begin{array}{l}\text { varch } \\
\text { ar }\end{array}$ & 12 & & $\begin{array}{l}\text { No } \\
\text { HP_pegawai }\end{array}$ \\
\hline
\end{tabular}

Tabel. 3. Struktur Tabel Data Alat

\begin{tabular}{|l|l|l|l|l|}
\hline Nama_Field & Type & $\begin{array}{l}\text { Wid } \\
\text { th }\end{array}$ & $\begin{array}{l}\text { Inde } \\
x\end{array}$ & Keterangan \\
\hline $\begin{array}{l}\text { Kd_equipm } \\
\text { ent }\end{array}$ & $\begin{array}{l}\text { varc } \\
\text { har }\end{array}$ & 15 & $\begin{array}{l}\text { Prim } \\
\text { ary } \\
\text { key }\end{array}$ & $\begin{array}{l}\text { Kode_Equipment } \\
\text { /Radio }\end{array}$ \\
\hline $\begin{array}{l}\text { Nama_peru } \\
\text { sahaan }\end{array}$ & $\begin{array}{l}\text { varc } \\
\text { har }\end{array}$ & 50 & $\begin{array}{l}\text { Nama_Perusahaa } \\
\text { n/instansi }\end{array}$ \\
\hline
\end{tabular}

\begin{tabular}{|l|l|l|l|l|}
\hline Status & $\begin{array}{l}\text { varc } \\
\text { ar }\end{array}$ & 20 & & Status_radio \\
\hline tanggal & $\begin{array}{l}\text { varc } \\
\text { har }\end{array}$ & 50 & & $\begin{array}{l}\text { Tanggal_pendafta } \\
\text { ran }\end{array}$ \\
\hline Freq & $\begin{array}{l}\text { varc } \\
\text { har }\end{array}$ & 50 & & Frequensi_radio \\
\hline bwidth & $\begin{array}{l}\text { varc } \\
\text { har }\end{array}$ & 20 & & Kecepatan \\
\hline ssid & $\begin{array}{l}\text { varc } \\
\text { har }\end{array}$ & 20 & & Tipe_stasiun \\
\hline
\end{tabular}

\section{IMPLEMENTASI DAN PEMBAHASAN}

\section{Kebutuhan Hadware}

1. Processor Intel core i3

2. Memory $4 \mathrm{~GB}$

3. Harddisk $500 \mathrm{~GB}$

4. CD Room Samsung 42x

5. Monitor, Keyboard, Mouse

6. Printer Cannon IP 2700

\section{Kebutuhan Software}

Perangkat lunak yang dibutuhkan untuk mendukung sistem ini adalah dengan menggunakan Sistem Operasi Windows7 Profesional, PHP, dan MySql Data Basenya

\section{Tampilan Home}

Tampilan home merupakan menu awal sistem ketika mengunjungi sistem tersebut, berikut merupakan gambar implementasi sistem tersebut

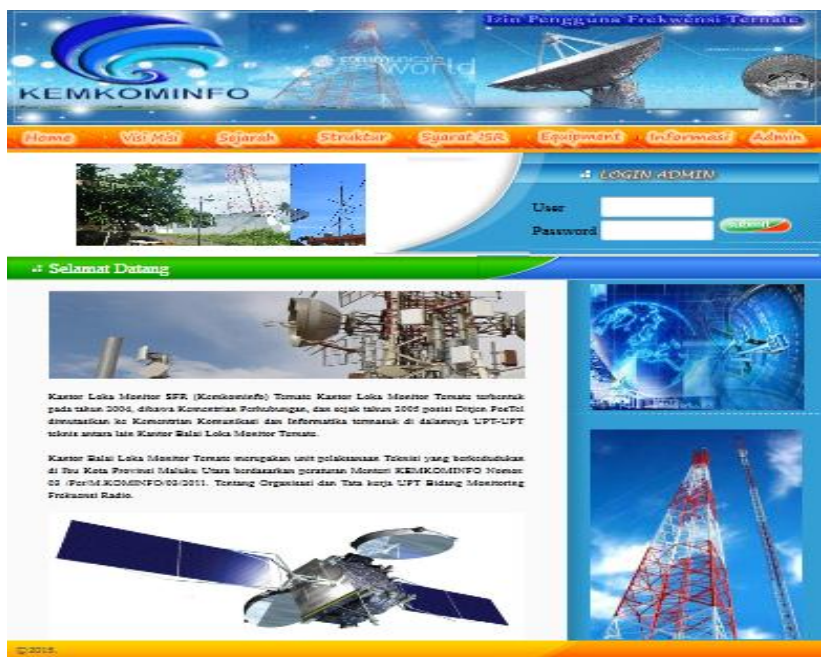

Gambar 9. Form Menu Home 


\section{Form Admin}
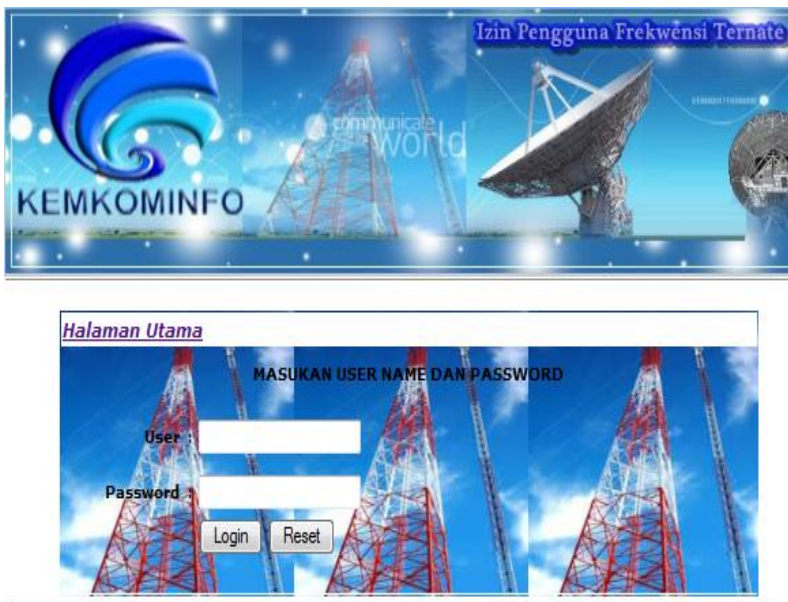

Gambar 10. Form Menu Admin

\section{Data Transaksi}

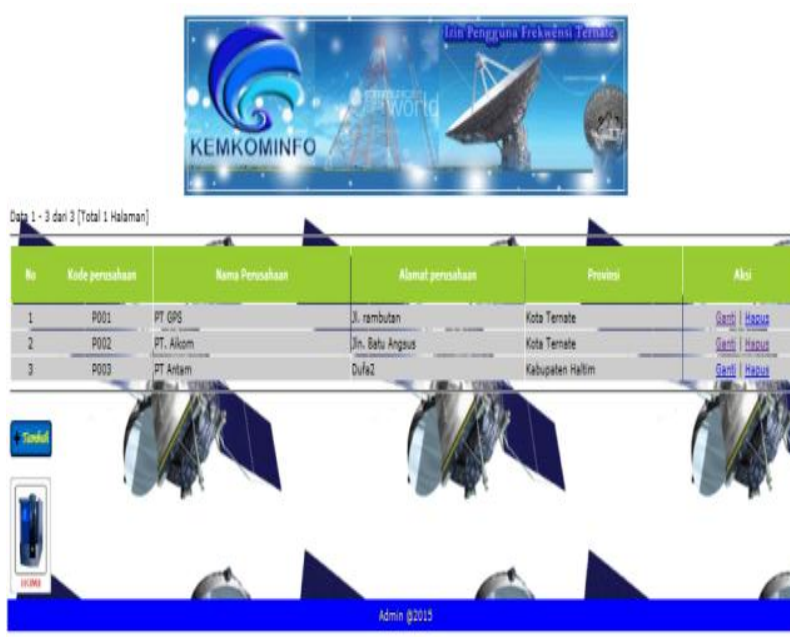

Gambar 11. Form Menu transaksi

\section{Data Pegawai}

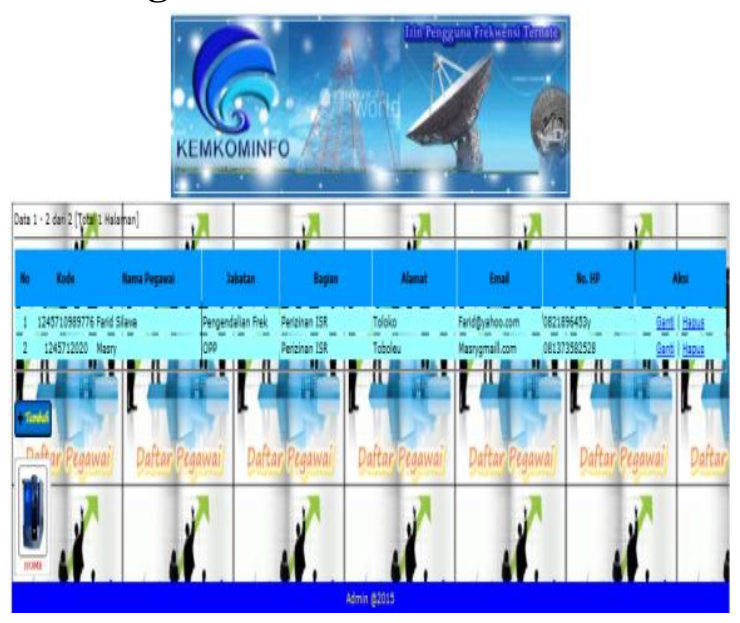

Gambar 12. Form Menu Pegawai

\section{Data Radio/Equipment}
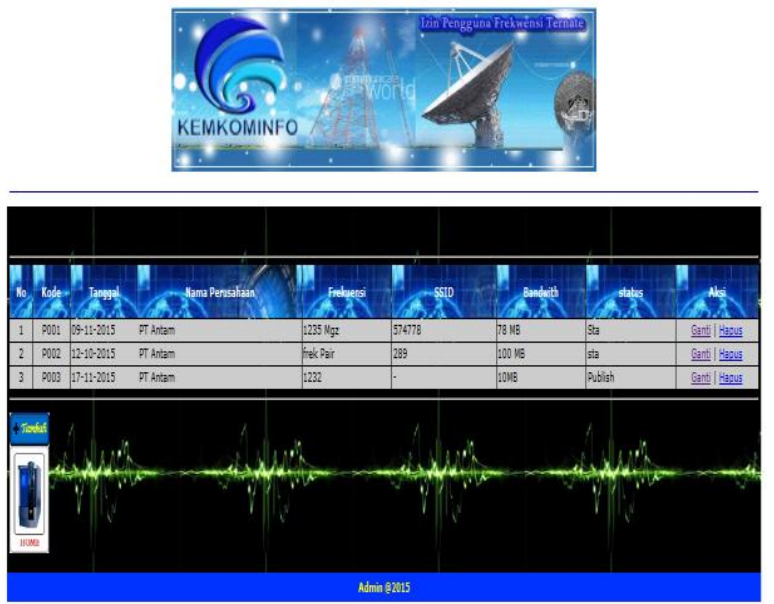

Gambar 13. Form Menu Data Radio

\section{Data Stasiun}
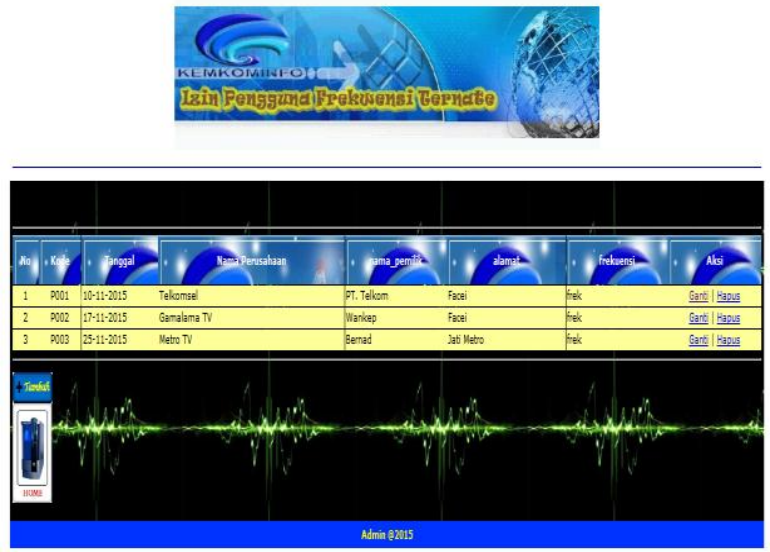

Gambar 14. Form Menu Data Stasiun

\section{KESIMPULAN}

Berdasarkan Implementasi dari uji coba program dapat disimpulkan bahwa analisis sistem berjalan khususnya pada bagian pengolahan data Pembuatan Izin Pengguna Frekuensi Radio pada Kantor Balai Loka Monitor Spektrum Frekeunsi Radio, (kemkominfo) Ternate, dalam hal pengolahan data Izin Stasiun Radio (ISR) yang menangani masalah pengajuan permohonan Izin stasiun Radio (ISR) dapat disimpulkan sebagai berikut:

1. mempermudah petugas, dan pemohon, untuk mengakses Program mengetahui tentang permohonan Izin Stasiun 
Radio (ISR) serta tempat pembuatan ISR

2. mempermuda pemohon dan pengguna ISR dalam mencari informasi yang berhubungan dengan pembuatan Izin Stasiun Radio (ISR) melalui internet yang bisa diakses masyarakat Maluku Utara khususnya dan masyarakat seluruh dunia pada umumnya

\section{Saran}

Berdasarkan kesimpulan dapat di sarankan sebagai berikut

1. Penerapan sistem kedisiplinan, mutu, dan fasilitas yang mendukung dalam proses pelayanan masyarakat untuk pengguna Izin Stasiun Radio (ISR), agar dapat melaksanakan segala sesuatu dengan cepat dan dibutuhkan sumber daya manusia yang benarbenar berbakat dalam bidang IT

2. Kedepan sistem tersebut dapat dikembangkan dengan desain tampilan form menu yang lebih baik dan menarik

\section{DAFTAR PUSTAKA}

Ahmadi, umar Fahmi, (1998), "Pengertian Rancangan System", Andi Offset Yogyakarta.

Andi Firmansyah, "Pembuatan database microsoft access (2003).

Davis, Gardon B. (1974), "Pengertian Informasi", Perbit Andi, Yogyakarta

M. Idham Abbas \& Zulfazri Muhammad, (2013), "Perancangan Sistem Informasi Data hewan pada Kantor Balai Karantina Kelas II Ternate.

Laporan Tahunan, (2013), "Balai Loka Monitor Spektrum Frekuensi Radio, (Kemkominfo)," Ternate.

Utami Yudi, (2001) "Perancangan Sistem Informasi Berbasis Web.

Wibowo, (2000), "Analisis dan Desain Sistem Informasi" Andi Offset Yogyakarta.
Undang - Undang no 36 tahun 1999 tentang telekomunikasi, tertib pengguna perangkat komunikasi, dan spektrum frekuensi radio.

Undang- Undang tahun 1945-1999 tentang Kementerian Komunikasi dan Informatika.

Departemen Komunikasi dan Informatika (2001-2005).

Kementrian Negara Komunikasi dan Informatika (2001-2005). 